\title{
Equity and social justice for whom and by whom in contemporary Swedish higher and adult education
}

\author{
Sangeeta Bagga-Gupta, Giulia Messina Dahlberg and Sylvi Vigmo
}

\begin{abstract}
This article focuses on the Swedish context of upper and post-upper secondary education provided in two sectors, universities and the Swedish Folk High School. The article is centred on the analysis of the support services offered by fifty-five university and Swedish Folk High School institutional websites to individuals and groups designated as being 'peripheral'. Taking as a point of departure a 'practiced policies' theoretical position, the study focuses on the 'situated nature' of institutional policies, that is, how policies become operationalised in local institutional contexts. Of interest is the nature of expectations placed on participants in the provision of support, and the ways in which different target groups are conceptualised and categorised. The findings of this national scale mapping, that build on two ongoing projects concerning equity and social justice, are discussed in terms of fundamental dimensions of democracy that shape students' opportunities to access upper and post-upper secondary education.
\end{abstract}

\section{KEYWORDS}

diversity, inclusion, integration, national case study, peripheral, transition

\section{Introduction, including a theoretical gaze}

This article is inspired by ongoing work in two ethnographically framed projects that focus on different 'named groups': people who are disabled and immigrants. The study can be understood as a spin-off from the intersections of these projects, each of which focuses primarily upon one named group that is generally identified as being 'peripheral'. In both projects, issues of equity and social justice in contemporary Sweden are centre-stage. 
Taking as a point of departure the challenges of the inclusion of disabled people and the integration of migrants that European societies face in the twenty-first century, the study contributes to the more general area of marginalisation and participation through a multidisciplinary engagement with areas that are usually dealt with in separate identity sectors (disability, ethnicity/race, etc.), institutional age-marked domains (preschool, school, teenagers, etc.), or specific support models. Our aim is not to argue that disabled people or immigrants share the same identity category or are considered as such in the framing of support in Swedish universities or in the Swedish Folk High School but rather to illuminate how issues of access play out for groups that are positioned as peripheral. According to Eva Kyndt et al. (2017), scant knowledge exists regarding support that individuals receive across the life-span, and the extent to which such support facilitates or hinders transitions into the post-upper secondary education life phase, and in particular into the open labour market and other dimensions of being an independent citizen in the contemporary world. In addition to contributing to gaps in the existing scholarship, this study is concerned with the situated and distributed nature of what the taken-for-granted terms inclusion and integration mean in contemporary democratic nation states. Inclusion and integration relate directly to equity and social justice in that they denote the aim of incorporating disabled people (inclusion) and immigrants (integration) into non-disabled groups and majority groups respectively.

The study attempts to unpack how inclusion and integration are operationalised and implicated in equity and social justice in general, and specifically in and across the institutional contexts of higher and adult education provided through universities in Sweden and Folkhögskolan (The Swedish Folk High School). The relationship between these institutional contexts is set out in Figure 1.

The present study sheds light on how policy framings shape institutional praxis and people's participation in higher education and adult education. We deploy the concept praxis to call attention to its aspiration for change in two specific ways. In a decolonial framing, praxis highlights the invisible hegemonies embedded in and across settings that shape how identity is understood; these hegemonies play out in mundane social actions, including in and through naming practices (Bagga-Gupta 2018). In a Marxist framing, praxis helps us to interrogate policy-related change. Gramsci (1975) contributes to a Marxian conceptualisation of praxis (see also Kemmis, 2012) in terms of a critical act in which diverse wills and purposes merge into 
a collective stance with the aim of making historical processes, including change, more coherent and 'action-oriented'. We argue that such an understanding of praxis may help shed light on the relationship between policy and practice in that policy aims to bring about change (to address seemingly 'new' societal needs, issues or challenges) through the homogenisation of disparate intentions by packaging them in a more coherent form, thus making change more efficient. An important consequence of this type of critical analytical position is that it illuminates tensions and contradictions related to a 'Catch 22 situation'; for instance, when a government's hegemonic apparatus manages to introduce (new) moral values, through educational institutions, that conform to certain views of the world or of democracy. This means that policies are introduced and implemented on the basis that such policies can address societal issues in a systematic and morally justifiable manner. In Bacchi's (2009) terms, policies contain implicit representations of what is considered to be the 'problem'. Thus, governance relates to how problems are constituted or in other words, 'problems' shape policy and policies create the problem. An understanding of praxis as a critical act acknowledges the primacy of scientific enquiry (Gramsci 1975) from non-normative positions, where the focus lies on the study and unveiling of the ideological and hegemonical stance of policies, even when the policy agenda seems to arise from morally justifiable intentions.

Similarly, but from a different trajectory, an ongoing epistemological shift in the field of policy studies pays attention to the performative dimensions of policies. Florence Bonacina-Pugh (2012), for instance, discusses this in the area of language policy: while " "policy" has traditionally been conceptualised as a notion separate from that of "practice" ... practices were usually analysed with a view to evaluate whether a policy is being implemented or resisted' (2012: 213). Such a shift towards performativity illuminates policies within practices themselves. While this ongoing shift puts social practices centre-stage, three closely related dimensions of policy have been identified. The first level consists of declared policies (formal texts or the formal understandings of how things ought to be done), the second of perceived policies (the beliefs and ideologies of what people think should be done) and the third level of practised policies (the social actions and interactions of people).

While we draw from these strands, the present study attempts to contribute to the ongoing epistemological shift by centring not only the formalised and often binding - policies at the national level, but also the ways in which universities and Swedish Folk High Schools make sense of these. Highlighting 
that it is individuals within institutions who operationalise these level-1 policies, the pragmatics of how these play out in institutional policies or plans become relevant. We understand these latter as level-2 policies; our point is that Bonacina-Pugh's third dimension regarding performativity can be expanded to include level-2 policies that offer a 'praxis' or a 'practiced' gaze that needs attention without getting entangled in a top-down implementation perspective. This means that recognising the epistemological shifts in the field of policy studies is an important step that illuminates the layered, overlapping and non-exclusive nature of 'declared', 'perceived' and 'practiced' policies in inclusion and integration (see Bagga-Gupta forthcoming). Looking across institutional settings and contrasting data thus enables situating the distributed nature of policies, in other words, how the declared natures of policies play out in the local contexts where people (future students, their support networks, etc.) engage with them (Lave and Wenger 1991); this points to the dialectic relationship of socio-cultural meaning-making processes that are both locally situated and distributed between people, tools and policies.

Focusing upon a single nation-state and the upper and post-upper secondary life phase may appear antithetical to our performative agentic perspective that builds upon an understanding that individuals 'do' identity with words and other tools (see for instance Bakhtin 1981; Butler 1997; Heath 1983) and thus that named-groups and nation-states are materially-discursively constituted in practices across time (Anderson 1991). Furthermore, the analytical focus on the nation-state of Sweden is relevant given the strong policy commitments established therein across time to equity, social justice and education. However, the study is not driven by a developmental agenda where a universalistic stance can allow a nation-state to be show-cased and compared with other nation-states. This means that this nation-state is a worthy case given the aims of this study. The university and Swedish Folk High School sectors constitute interesting sites of analytical engagement for our focus on the upper and post-upper secondary life phase, that is, individuals who are 18-years and above. This constitutes a transitional life phase marked by independence from the primary family unit and a period when individuals establish their own life arenas. What it means to transit into identity-positions of adulthood is different in different past and contemporary contexts i.e. this is not a universal pathway; in a nation-state like Sweden this transition implicates living on one's own and participating in higher education and/or work arenas. This is not the case for many societal settings 
across the globe. For instance, participating in work arenas is gendered in many communities and living on one's own is not a cultural pattern in many.

While social justice, including provision that is based on equity, constitutes a taken-for-granted agenda in many democratic societies, understanding practiced policies as these become inscribed across institutions is important analytically for illuminating how inclusion and integration are conceptualised. In the literature, the two named groups focused on in the present study, as well as the university and Swedish Folk High School sectors, are framed as separate fields of scholarship; for example, special education or disability studies, migration studies or ethnicity studies, and higher education or adult education. By focusing upon two named groups - functionally disabled people and immigrants - in a common study, our aim is to centre-stage the more overarching issue of how democratic societies - here exemplified by the nation state of Sweden - attend to issues of equity and inclusion/integration from the praxis and practiced policy perspectives outlined above. We further explicate the need to focus on different educational institutions - universities and university colleges, and the Swedish Folk High School - that target different populations and that have different agendas, in the third section.

Taking cross-sector points of departure, this study centre-stages issues of functionality and ethnicity (the latter in terms of newer or older and established migrants). More specifically, it attempts to illuminate the provision of support, including digital and technological support, to individuals and named groups that are understood as being on the periphery in policy contexts, by investigating,

1. the ways in which targeted recipients of support are defined and discussed;

2. the kinds of needs that are made (in)visible and the nature of support that is highlighted in these institutional settings;

3. the expectations that are placed on participants (students, faculty, administrators, etc.) from the institutions for their own inclusion and integration;

4. the differences and similarities, if any, that can be noted between the provision provided by the Swedish Folk High School and university sectors.

The next section presents a methodological note on the data and analysis, including the analytical pathways deployed. The third section presents the 
specific nature, scope and historical developments of the higher education and Swedish Folk High School sectors. Here, an outline of the general laws and policies that govern these educational institutions, and issues raised about them in the existing scholarship, are also highlighted. The fourth section presents three themes that have been identified in the analysis. These themes are related to the topography of the situated-distributed, the locally performed, nature of equity and social justice across people and contexts. The paper concludes with a discussion section where we also present some overarching implications from the present study.

\section{A methodological note on the data and analysis}

This article draws on work being conducted in the Swedish Research Council project 'Participation for all? School and post-school pathways of young people with functional disabilities' (PAL), where, in addition to the larger group labelled as the 'functionally different', two named groups of functionally disabled children and adults are focused upon (those who are deaf and those with a ADHD diagnosis). In addition, this study draws upon datasets from the 'Integration project' that is partly supported by the Social Sciences and Humanities Research Council of Canada. The life trajectories of recent Syrian migrants are being mapped in two regions of Sweden and one region in Canada in this project. Equity and social justice are key issues in both projects, and our interest lies in understanding how these play out in the provision of support by educational and other societal institutions.

In 2019, there were 155 independent units of the Swedish Folk High School and more than 31 Swedish universities (14 public universities, 17 public university colleges and a number of independent higher education institutions) (Sweden.se 2020). Our analysis has focused on the support services that the websites of 55 institutions (35 universities and university colleges and 20 Swedish Folk High School units) offer individuals and named groups that are designated as being peripheral (in this case, disabled people and immigrants). Such support is highly significant in shaping access to educational opportunities for these named groups.

We mapped the overarching resources, that is, the level-1 policies, before zooming into the level- 2 policies in the dataset. In the first mapping step we adopted a future student's position and searched the fifty-five websites for information about studying with disabilities and the language options available for students who do not know Swedish. This approach builds upon 
our experiences from the long-term shadowing of individuals in the PAL project, including discussions about the gatekeeping dimensions of policies encountered by our students in higher education institutional settings. We also observed two people in the PAL project and one person in the Integration project as they navigated the websites of one Swedish University and one Swedish Folk High School, in order to understand the reliability of this approach. An inductive ethnographical approach was adopted in the present research, during which the semiotic textual resources (written texts, still and moving pictures, their dispositions, colours, and so on) on the website dataset were studied. This open-ended scrutiny was conducted with the aim of identifying common trends in the data, emergent and recurring themes and issues and aspects that stood out. Thus, the overarching methodological approach included the perspective of a future student who needs information about accessibility for disabilities and/or has no or limited knowledge of Swedish; their ease of access to necessary information; and what distinguished the information available online.

The process of data creation started by searching for specific institutional websites on the World Wide Web, with search words like 'student support' (Swedish: studentstöd) and 'study with disabilities' (studera med funktionsnedsättning). Further scrutiny involved locating where relevant information was available, that is, issues of visibility and accessibility. This included investigating the website display: for example, font size, placement on the site and visibility, colour contrast, whether text-to-voice and information in Swedish Sign Language (Svenskt TeckenSpråk, henceforth STS) were available, and what language options were clickable. Images were also examined to identify descriptive alternative tags (to support applications for people who are visually impaired), who is represented in pictures, and whether they were mere illustrations or potential bearers of essential information. Once relevant pages on student support were identified, the process continued by clicking on the links available on the identified pages. Links to pages external to the university/Folk High School domain were noted but not included in the dataset that we created through this process. The websites were explored on laptops and desktop computers, not on mobile devices.

In addition to creating the data through these steps, our analytical process involved investigating data systematically (and reliably) in terms of how the data were identified, chosen, and stored. A built-in feature on Google Chrome enabled the capture of full-page screenshots of the websites as PNG files that were added to the data corpus and stored in digital folders. This 
feature made it possible to go beyond a restricted view of the website that is dependent on screen size. It instead offered a way of visualising the page in its entirety, from top to bottom in one picture (see for instance Figures 1, 2, 3, 4, 6, and 7).

Online scraping of web data (as one way to understand our approach) is not only 'a technique', but also 'an analytical practice' (Marres and Weltevrede 2013: 317, original emphasis). While it is important to note that we did not use digital scraping tools, we draw on the notion of scraping as part of the analysis of data created from existing websites, that is, a 'multifaceted phenomenon' (Marres and Weltevrede 2013: 319). When one handles online scraping, it is important to consider the boundaries of the field (and its questions) that provide opportunities to include what is interesting from what can potentially disturb the analytical work. Once recurring themes were identified (at our regular data sessions and when we presented our initial findings at international research conferences), some websites were analysed further through finely tuned steps, with the aim of capturing the website structure in depth.

Searching the websites for relevant information about educational opportunities for individuals with disabilities, including the various languages in which information circulates, can metaphorically be described as uncharted territory. The links to educational opportunities for individuals with issues of functionality are characterised by diverse ways of reaching relevant information. The steps described here are, to our knowledge, not commonly addressed methodologically in the scholarship where peripheral identitypositions are centre-staged (for further discussion on this point, see BaggaGupta and Messina Dahlberg forthcoming). The nature of the evolution of declared policies in place is discussed in the next section, and in the section after that we present the nature of practiced policies.

\section{Historical trajectories: Laws, policy, and scholarship regarding inclusion and integration}

The two sectors examined in this study, Swedish universities and the Swedish Folk High School (see the orange highlighted boxes in Figure 1) provide education at the upper and post-upper secondary levels. The Swedish Folk High School is a distinctive educational provision, available in Sweden and Denmark. From a global perspective, it is viewed as a Nordic model. The emergence of the Folk High School in Sweden in the mid-1800s was marked 


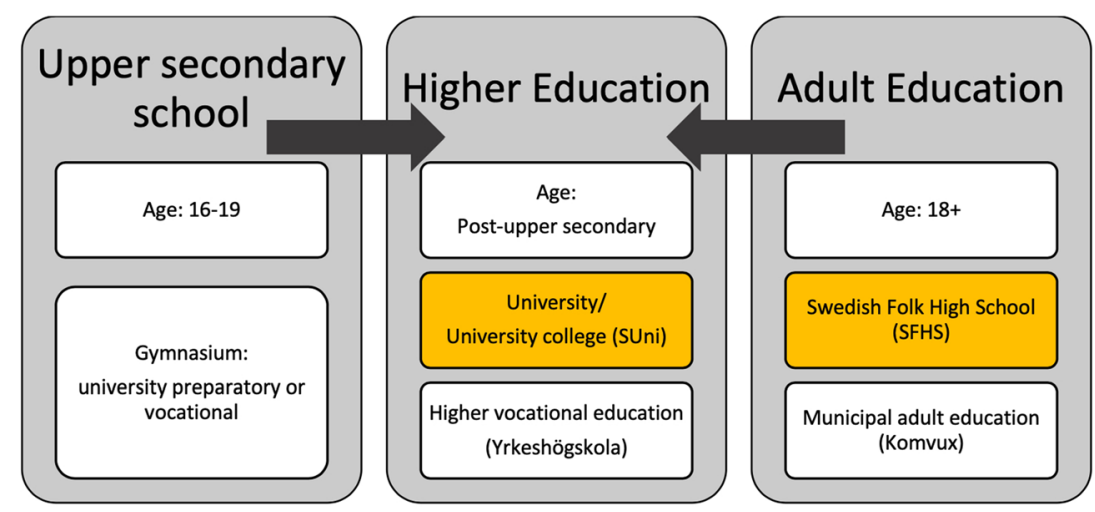

Figure 1. Educational arenas in Sweden: School, Higher Education and Adult Education. The educational institutions focused on in this study are marked orange.

initially by a traditional school form, but with emphasis on the key pedagogical goals of democracy, autonomy and social mobility (Fejes et al. 2018). Since its inception, the aim of the Swedish Folk High School has been to deliver and share 'Bildung' (self-cultivation and personal growth) in Sweden. This continues to be a relevant aim in the twenty-first century (SFS 2015). Together with two other institutions, municipal adult education (Komvux) and the upper secondary school (Gymnasium), the Swedish Folk High School is tasked with the provision of education that fulfils the general requirements for accessing higher education.

A specific aim of the Swedish Folk High School is to offer general courses to participants from diverse backgrounds. While upper secondary school caters to individuals under 20 years of age, the Swedish Folk High School and municipal adult education are open only to individuals above 18 years of age. While municipal adult education has its own national curriculum, the Swedish Folk High School has no national curriculum that works as a jurisdictional framework for its functioning.

Dörte Bernhard and Per Andersson (2017) highlight that the Swedish Folk High School currently takes in larger groups of participants who, during their primary and secondary schooling in the 1990s received different disability diagnoses. Ability or functionality has become another dimension of diversity in adult education, together with age, gender, class, and ethnicity. This means that the last two decades have seen individuals whose functionality does not conform to the norm become part of the student demographic in 
adult education. Interestingly, but perhaps not surprisingly, the questionnaire-based study by Bernhard and Andersson (2017: 93) reports that:

both Statistics Sweden and self-reports ... give evidence that people with neuro-psychiatric disability are to be seen as a growing group and are even said to be the largest group at [the Swedish Folk High School] regarding participants with a disability.

Historically, Swedish universities too have aimed to create wider access and participation in line with the agendas of a democratic and globally competitive society. This can be noted in Swedish policy and reports since the Second World War, and most recently in a 2019 UHR publication entitled 'One university for all' [En högskola för alla] (UHR 2019). This means that similarly to the developments in the school and Swedish Folk High School sectors, Swedish universities have undergone changes that are both the result of, and constitute a leading factor in, the emergence of institutions where social mobility, non-segregation, and equality are clearly on the agenda.

Having said this, a key contemporary concern of Swedish universities is to highlight the ways in which they are distinct from the Swedish Folk High School sector in the ways in which they address issues of transitions and participation for a diverse population of students (Kyndt et al. 2017; UHR 2018; UKÄ 2018). For instance, while issues related to widening participation were, until recently, considered problematic for the university sector, it currently faces challenges related to a growing heterogeneity of its student population marked primarily in terms of ethnicity, functionality and socioeconomic background. This is interesting given the historically framed openness of the sector regarding student demographics ever since the Second World War. This inclusiveness can be traced through the economic wellbeing of the 1950s and the social equity goals of the 1960s when higher education planning was based on factual and future societal needs. Across time, the political agenda has consistently been about increasing access to higher education for larger cohorts of students, rational reorganisation of higher education in light of societal needs, and the delivery of high-quality education and Bildung (in terms of general competencies, perhaps).

A recent Swedish Council for Higher Education report (UHR 2018) on the situation for students with disabilities in Swedish universities highlights that this group routinely gains access to higher education via municipal adult education or the Swedish Folk High School. According to the UHR report, 
this is especially the case with students who are diagnosed with dyslexia, dyscalculia or neuropsychiatric functional disabilities. These developments suggest that it takes longer for people with such diagnoses and functionality issues to access higher education: in addition to the thirteen years of primary and secondary schooling, they spend two years at the Swedish Folk High School as well. While this can be accounted for in different ways, what is relevant for the present purposes is to investigate the nature of the Swedish Folk High School's situated policy of support and how it is made available. The present study undertakes this task by scrutinising their websites for their level-2 policies. Since students with a neuropsychiatric functional disability diagnosis have also increased in numbers at Swedish universities, a comparison between the two types of institution can potentially illuminate the ways in which different expectations are imposed on participants in the provision of support itself, as well as the ways in which different target groups are conceptualised and categorised.

The UHR report mentioned above also indicates that students with dyslexia, dyscalculia, or neuropsychiatric functional disabilities are most likely to make contact with, and have gained support from, administrators and counsellors at the student support services. Students who have sensory impairment (visual and/or auditory) are, in contrast, the least likely to get in touch with a counsellor for various reasons. This trend is also confirmed in the Swedish Higher Education Authority's 2018 annual report (UKÄ 2018): 7598 students with dyslexia and 3668 students with neuropsychiatric functional disabilities are reported to have been in contact with a counsellor and to have received university support, while only 285 students with visual impairment, 260 with a hearing impairment and without interpreters and 108 with interpreters are reported to have done so.

There are no references to group heterogeneity or inclusion and integration in the two central policies that frame Swedish universities, the Higher Education Act and the Higher Education Ordinance; these issues are instead addressed in the 2001 proposal and the 2017 Promemoria (see Table 1). The activities of both Swedish universities and Swedish Folk High School institutions are organised within the framework of the Swedish law, including the Discrimination Act (2008) and the convention on the rights for persons with disability that Sweden signed in 2007 (Utrikesdepartementet 2008); see Table 1. 
Table 1. Current general laws and policies related to inclusion and integration that frame the work of Swedish universities, university colleges and the Swedish Folk High School.

\begin{tabular}{|c|c|}
\hline \multicolumn{2}{|c|}{$\begin{array}{c}\text { Swedish Law } \\
\text { Discrimination Act } \\
\text { Convention on the Rights for Persons with Disabilities }\end{array}$} \\
\hline $\begin{array}{l}\text { Swedish Universities and University } \\
\text { Colleges }\end{array}$ & The Swedish Folk High Schools \\
\hline $\begin{array}{l}\text { - The Higher Education Act } \\
\text { - The Higher Education Ordinance } \\
\text { - Statute Book of the Swedish Council } \\
\text { for Higher Education } \\
\text { - Prop. 2001/02:15 “The Open } \\
\text { University” } \\
\text { - Promemoria widening participation in } \\
\text { Higher Education U2017/03082/UH }\end{array}$ & $\begin{array}{l}\text { - Law concerning state funding for } \\
\text { folk education SFS } 2015 / 218 \\
\text { - Guidelines for the folk high school } \\
\text { education council about the right to } \\
\text { study (studeranderätt) } \\
\text { - Guidelines for the folk high } \\
\text { school education council about } \\
\text { competence certification } \\
\text { - Ten quick facts about folk high } \\
\text { school } \\
\text { - The Swedish Folk High Schools } \\
\text { (Folk high school information } \\
\text { service - FIN) }\end{array}$ \\
\hline
\end{tabular}

The Swedish Folk High School sector, as highlighted earlier, is not governed by a national policy and curriculum. The only document that refers to inclusion in this sector is a leaflet called 'Ten quick facts about SFHS' (Folkhögskolornas informationstjänst 2017). Here accessibility and openness for everyone is briefly highlighted:

Many SFHS institutions offer customised teaching, social support, and an accessible environment for participants with disabilities. There are also courses that are offered specifically for those of you with disabilities (our translation). ${ }^{1}$

This section has covered the historical trajectories, some relevant scholarship and the nature of the level-1 policies pertaining to the two educational institutions that are the subject of this study. The next section turns attention to the analysis of the level-2 policies, from which three themes have emerged. 


\section{The topography of the situated-distributed nature of equity and social justice}

Three salient overlapping themes - policy availability in digital and online spaces, entry points and default routes, and the challenges and tensions related to (in)visibility - have emerged from our ethnographical gaze at the extensive digital and online dataset created from the websites of the fifty-five Swedish universities and Swedish Folk High School institutions. This section presents these themes, illustrating them through data citations and pictures and from the analytical pathways explained earlier.

\section{Policy availability in digital and online spaces}

There are routine references to national and local policy and regulations concerning inclusion, integration and accessibility on the Swedish university and Swedish Folk High School websites. Swedish universities in particular have dedicated websites that display the kinds of provision that are available for students in need of special support and those with functional disabilities and the ways in which these can be accessed. For instance, Högskolan Väst (University College Väst) has a direct reference to the Discrimination Act on the website dedicated to students with functional disability. What is meant by a functional disability is spelt out here (see Figure 2).

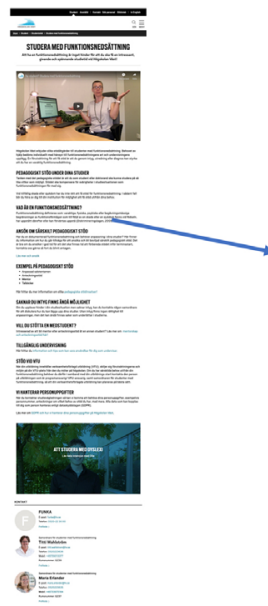

\section{VAD ÄR EN FUNKTIONSNEDSÄTTNING?}

Funktionsnedsättning definieras som: varaktiga, fysiska, psykiska eller begåvningsmässiga begränsningar av funktionsförmågan som till följd av en skada eller en sjukdom fanns vid födseln. har uppstătt därefter eller kan förväntas uppstå (Diskrimineringslagen, 2008:567)

Figure 2. Högskolan Väst. Capture of the full-page screenshot of the website (left). Zooming into the central area of the page (right). Translation from Swedish in the text box. https://www.hv.se/student/studentstod/studera-med-funktionsnedsattning/. 
Reference is also made to the exact same definition from the Discrimination Act on the website of Uppsala University and other university websites in the dataset. The Discrimination Act is used by these institutions to determine or identify - based on specific characteristics - which students can access the 'special pedagogical support' (särskilt pedagogiskt stöd) that they make available. While two different websites at Uppsala University deal with support for all students and the 'special' support specifically tailored for students with a permanent disability in line with the Discrimination Act, a third website spells out how students can apply for the special pedagogical support (Figure 3). In contrast, Swedish Folk High School websites in the dataset do not refer to national policy or laws (level-1 policies), and information about the support provided to students follows a different logic (see theme 2 below). Furthermore, not all Swedish Folk High School institutions provide this type of support.

Figure 3 also shows different images on the right-hand side, depicting what can be identified as study or work-related activities. All the images here focus on some part of the human anatomy, and in two of them digital technology is visible: a digital calendar, perhaps hinting at the support provided to all students in relation to their abilities (or lack thereof) to plan their studies and avoid stress; and a laptop used to type, perhaps in

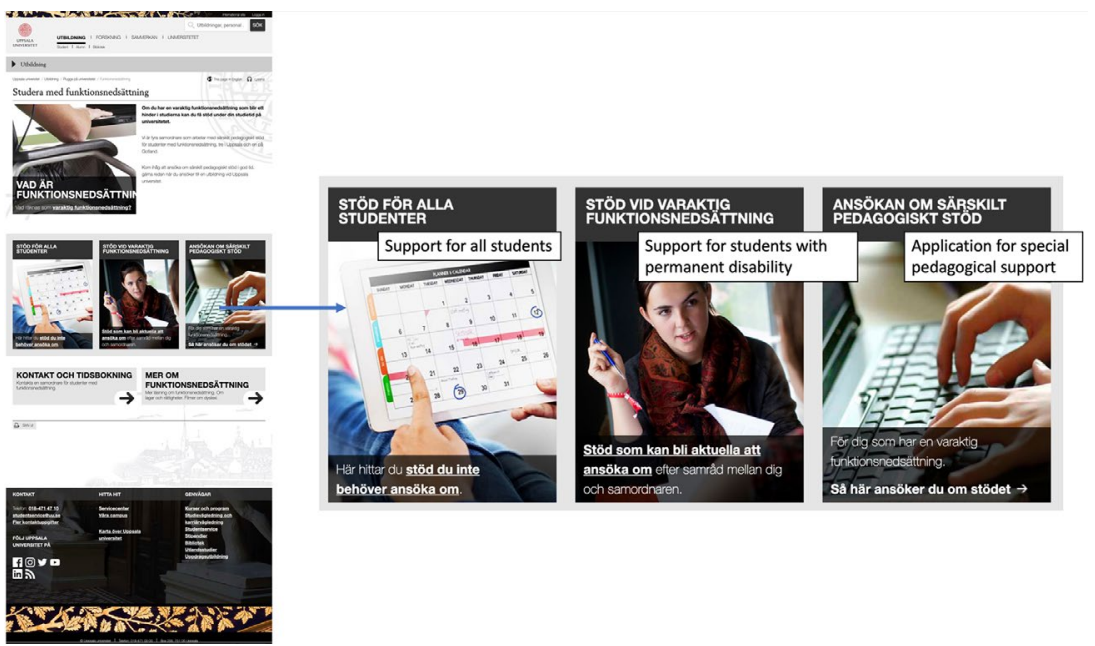

Figure 3. Uppsala University. Capture of the full-page screenshot of the website (left). Zooming into the central area of the page (right). Translation from Swedish in the text boxes. https://www.uu.se/utbildning/plugga-pa-universitetet/funktionshinder/. 
relation to the application that must be sent in order to get the support if a person belongs to the group of people with permanent disabilities. Caring for students' health in general and attending to the needs of students with disabilities in particular, are concerns that are displayed on the university websites in similar ways. These websites also highlight students' rights as well as responsibilities. References to local and national policy documents furthermore legitimise how support is tailored and for whom. Such displays of policy - at level 2 - in digital spaces, and the rather fixed and specific steps that students are required to take to avail themselves of the special support, constitute evidence of practiced policy in both the higher education and the Swedish Folk High School sectors.

\section{Entry points and default routes}

Institutions in the Swedish university sector offer a rather clear and standard default route for students who need information about support services. The Swedish Folk High School, by contrast, appears to have a diffuse route for students whose functionalities differ from the taken-for-granted norm or for those who are in need of learning Swedish. Entry points and default routes that are available for students, and/or those who mediate the digital and online spaces for students, constitute the second theme regarding the practiced policies of the higher and adult education landscape in Sweden. The Swedish university dataset often displays a series of requirements that create a sort of default route that students must take, in which the National Administration and Information System for coordinators (NAIS) at the Swedish Council for Higher Education has a central place. This default route is also relevant to what is expected of a new student for obtaining support. A common pattern involves a student (or their representative) sending a request online for special support through NAIS, together with a medical document certifying the permanent nature of their disabilities. This request or application is thereafter assessed by an administrator and/or a coordinator at the university student support services. The next step involves a personal meeting that the student initiates. The student is expected to contact and meet a study counsellor (studievägledare) at the university where they have applied to study. The dataset does not clarify where responsibilities lie with regards to faculty engagement at the level of the course/programme that the student has applied to join. The default route can be illustrated by the steps spelled out on the University of Gothenburg's website regarding special peda- 
gogical support, from the website 'About studying with functional disability'2 (Studera med funktionsnedsättning):

1. the student sends a request for special support on the NAIS portal together with a medical certificate;

2. the request is evaluated by an administrator at the student support service centre;

3. the student and the administrator have a meeting;

4. the student contacts the study counsellor for the programme/course on which they have been accepted.

A similar route, albeit with different degrees of detail and in different formats, is available on the university websites in the dataset. Only one university website (University of Skövde) presents information in Swedish Sign Language (STS). While this information is available at the bottom of the homepage of the website under the link 'Genvägar' (short-cut), the STS video is not available on the page for support for students. Thus, although most websites in the dataset are text-based, some exceptions enable oral renditions of written text.

In contrast to universities, Swedish Folk High School websites that communicate information about accessibility of support tend to do this under a common label, 'Rights to study' (Studeranderätt). Only some Swedish Folk High School websites present this information on their homepage. With very few exceptions, the websites require several clicks to locate information about 'Rights to study'.

A specific pattern in the data that pertains to both sectors relates to how a website presents information for new students. The two sectors present this information in very different ways. The framing tends to be more straightforward on Swedish Folk High School websites. At times, the profile is directed at specific named groups (e.g. PRO SFHS for retired elderly people), for specific language users (e.g. Mo Gård 3 SFHS for STS users), or specific themes (e.g. Leksand SFHS for craftwork, Gotland SFHS for aesthetics). Only some Swedish Folk High School websites present this information on their homepage. With very few exceptions, several clicks are required to locate information about 'Rights to study'. Support is primarily available for individuals with dyslexia and dyscalculia, those who lack knowledge of Swedish and those who require support for access to physical buildings and for academic writing. An exception is Biskop Arnö Swedish Folk High School, 
which, like universities and university colleges, requires participants with functional disabilities to furnish a medical certificate (läkarintyg) to access support. However, unlike university requirements, there are no connections to the NAIS system to access the support. Functional disabilities - intellectual, sensory and mobility-related - are often discussed on websites in both sectors, in terms of the provision of support services alongside support that is made available for immigrants or 'new migrants' (nyanlända).

In contrast to the university dataset, where English pages are almost always available, direct links to other languages are rarely available on the Swedish Folk High School websites (with the exception of Mo Gård, where videos in STS are available on every page together with information in written Swedish). Out of the twenty Swedish Folk High School units in our dataset, sixteen websites are entirely monolingual, displaying all information in written Swedish only. In addition to the information in Swedish, three offer information in English and one also in German. STS is offered by very few, and six have a 'talking web': a speech synthesis application that converts the content of the page and enables information access in modalities other than written Swedish.

Courses that teach Swedish as an additional and new language for adults (Svenska för invandrare) are offered by one third of the Swedish Folk High School institutions in the dataset. Given that most of the websites are monolingual, access points to information about courses for learning Swedish as a new language require mediation by a person who knows Swedish. The few courses that address disability are mainly offered as education about disabilities, with two exceptions where courses target a named group of disabled students. For instance, one course in the dataset targets students with an Autism spectrum diagnosis, and another offers a drama course for people with disabilities. Furthermore, courses for learning STS are offered by two Swedish Folk High School institutions in our dataset.

\section{(In)visibility and nature of support}

Information regarding services available is very similar across the universitysector websites that specifically address students in need of special educational support (see theme 1 above). The Swedish Folk High School sector, as we have also seen, differs. However, one can say that while the visibility of support is clear-cut in the higher education sector, some of its parameters are not clear, and the presentation of support is, in comparison, invisible 


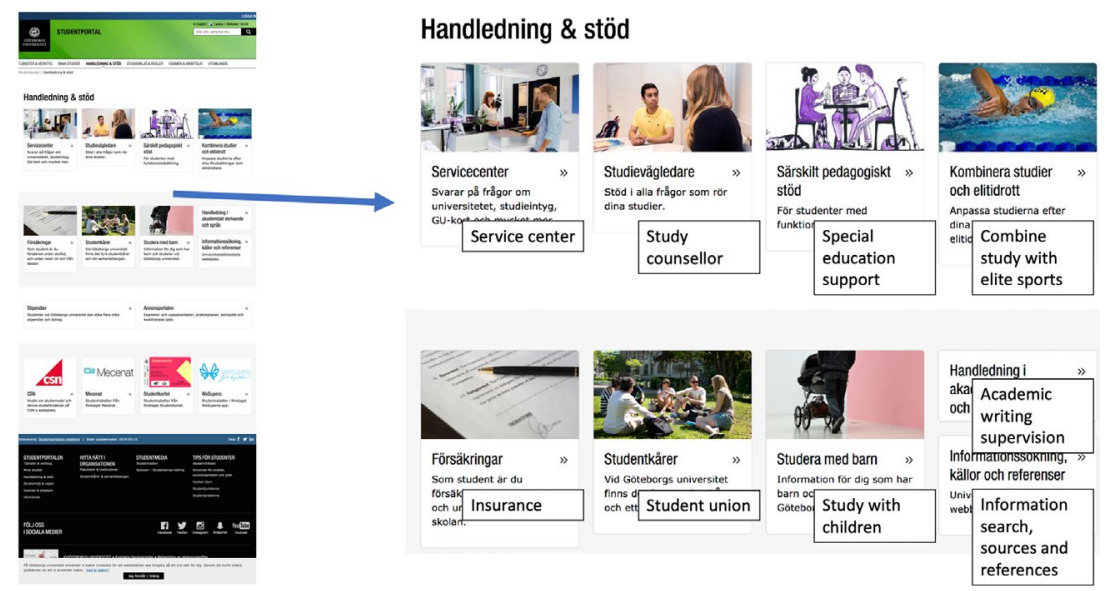

Figure 4. University of Gothenburg. Capture of the full-page screenshot of the website (left). Zooming into the central area of the page (right). Translation from Swedish in the text boxes. https://studentportal.gu.se/handledning-och-stod.

in the Swedish Folk High School dataset. Figure 4 illustrates this through a university website entitled 'supervision and support', which presents the institution's services for named groups through pictures and titles. Either real people, objects, or in one case, a drawing illustrate specific issues in each picture. These pictures demonstrate the special educational support that is available for students with functional disabilities. The monochromatic drawing in Figure 5 - which is part of the batch of pictures presented in Figure 4 - depicts three people chatting and perhaps enjoying a cold drink at a table. This drawing includes a dog, a bag and a crutch behind one of the seated people. The crutch constitutes the only visible reference to a disability.
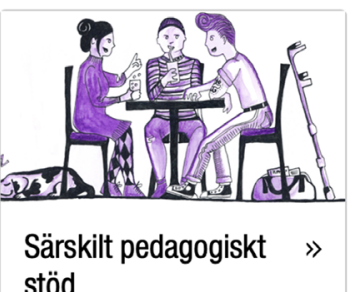
stöd

För studenter med funktionsnedsättning.

Special education support

For students with functional disability.

Some institutions provide support that is narrow and directed towards one specific named group. One Swedish Folk High School in the dataset advises potential

Figure 5. Pictorial illustration and a link to the page about special educational support at a Swedish university (University of Gothenburg). Translation from Swedish in the text box. 


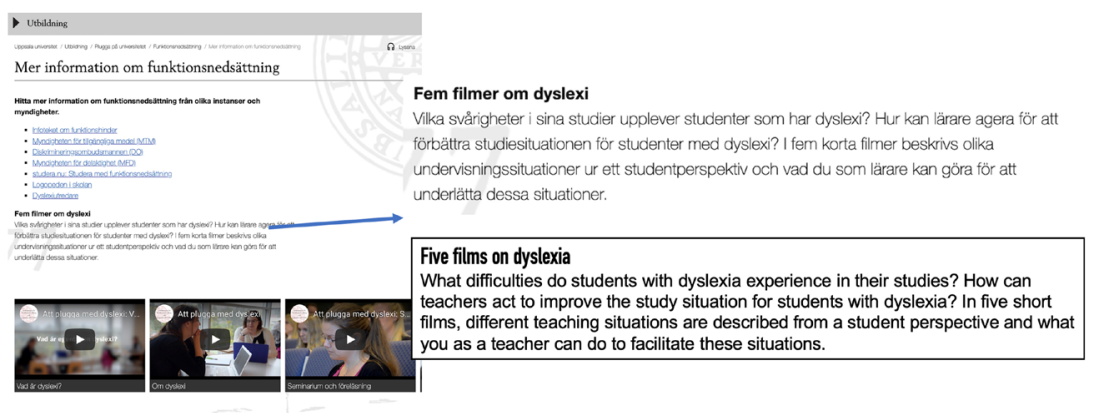

Figure 6. Uppsala University. Screenshot of part of the website (left). Zooming into the central area of the page (right). Translation from Swedish in the text box. https://www.uu.se/utbildning/plugga-pa-universitetet/funktionshinder/ mer-information-om-funktionsnedsattning/.

students with disabilities to apply elsewhere. While there are several courses at both higher education and Swedish Folk High School institutions that aim to prepare students for working with peripheral named groups, in a small number of cases, courses are specially designed for individuals at the periphery. These include courses in STS and courses for immigrants who are either learning Swedish or who need extra courses to continue working in the professions for which they have qualifications from the contexts they have migrated from.

The datasets also indicate a clear-cut focus on specific disabilities. For instance, many Swedish university sector websites about support for students with functional disabilities are related to dyslexia. Karolinska Institute, Högskolan Väst, Lund University, Umeå University, and Uppsala University (see Figure 6) constitute examples.

The range of support that is available and offered, particularly by Swedish Folk High School institutions, is characterised by diverse approaches in terms of what is targeted, how support is presented, expressed, visualised and who is addressed. Examples of earmarked support provision are study workshops (for successful studies); websites linked to student health and lifestyle; disabilities and support during studies; rights and regulations; student unions; and general services that can be accessed at the institutions' information centres. Real life stories are also displayed on the websites to illustrate successful cases.

Groups commonly targeted for support provision across the dataset include students with a permanent disability, those with dyslexia (see 
Figure 6) and dyscalculia, and students in need of language support related to academic writing and academic studies more generally. Academic writing, particular in the university sector, is streamlined through tailored study pace and examination forms, notes support, mentor support and software for reading and spelling. Irrespective of what support provision is provided and for whom, locating relevant information (from a student's gaze, as we have seen in the two previous themes) calls for a thorough website search using specific terms, such as support and disability, in order to identify support for academic studies.

Even though the Swedish Folk High School sector often specifically targets differently abled students, websites that clearly present their support services like the one presented in Figure 7 are exceptions in the data. Mo Gård, for instance, an STS-language-profile Swedish Folk High School, implicitly targets students who are deaf (but also those who are hard-of-hearing and those who have no hearing problems). Its homepage includes a video where a staff member presents the school in STS (see Figure 7). Its foci are formulated on its website as follows:

Mo Gård is a foundation-owned non-profit organization that offers support and service, treatment, education, and knowledge support. Our areas of strength are communication and disability. ${ }^{4}$

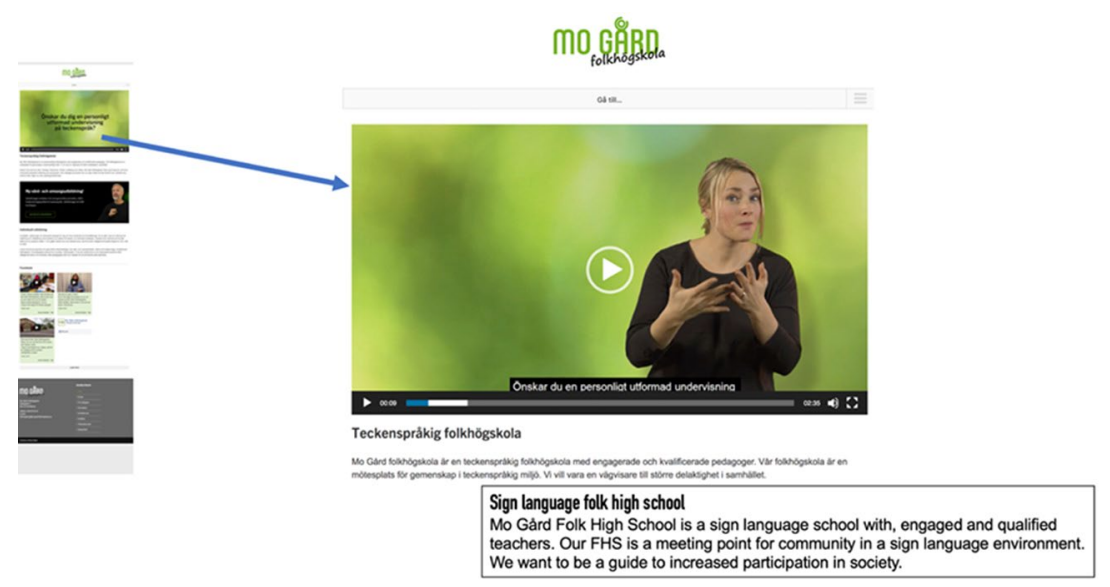

Figure 7. Mo Gård Swedish Folk High School. Capture of the full-page screenshot of the website (left). Zooming into the top area of the page (right). Translation from Swedish in the text box. www.mogardfolkhogskola.se. 
From the analysis of the homepage and its different links, it was not possible to find information about where the kinds of support and services are presented. It seems that disability, accessibility, and inclusion are not issues in need of specific foregrounding for this Swedish Folk High School, but rather, that they constitute a natural dimension of the targeted groups it aims to attract. This Swedish Folk High School offers support for a named language-focused group in society (in this case, the signed language community).

At an overarching level, the three interrelated themes that have been explored in this section unpack level-2 policies. This responds to a practiced policy analysis where the focus is digital data across societal arenas. The final section of this article attempts to discuss the overarching findings of this study, including implications for higher and adult education in settings in the Global North more generally.

\section{Discussion and implications}

The focus in this study on the provision of support for individuals and named groups understood as lying at the periphery highlights some paradoxes and tensions related to issues of naming and categorisation. In addition to presenting a birds-eye view of the overarching support that is provided nationally at the upper and post-upper-secondary life phase, the differences and similarities between the provision provided by the university and Swedish Folk High School sectors are salient. An interesting issue is the economic support provided to the Swedish Folk High School sector in the aftermath of the most recent immigration wave in Europe in 2015, which has created a stabilisation of this sector. This means that the arrival of refugees led to allocation of support to this sector; this thus constitutes a significant issue for understanding how targeted named groups are supported. Such support has direct implications for named groups' access to opportunities at the upper and post-upper secondary levels within higher and adult education. For instance, the analysis confirms the Swedish Folk High School's historical trajectory as a support sector that targets specific non-mainstream groups in society to help them enter the job and education landscape. The university sector too has been attempting to solve the issue of widening recruitment and participation across the past two decades, in ways that the Swedish Folk High School sector has been doing for a century. This issue is however not without complex dilemmas. As illustrated in Figure 1, different and parallel pathways 
exist for entering higher education in Sweden: through the mainstream path of school (from kindergarten to upper secondary), or through adult education, of which the Swedish Folk High School is one sector and municipal adult education another. Thus, dilemmas related to the issues of how support provision is earmarked for individuals and named groups in higher education and adult education are complex, as this study has explicated. Furthermore, support appears to be framed by both a normalising and a conserving agenda in both arenas, wherein the focus lies on the one hand on institutional ways of finding universal solutions for inclusion and integration within higher and adult education, and on the other hand on retaining the peripheral identity of the named groups who can make claims on the support, either via the rather established default route in the university sector, or the fuzzier path in the Swedish Folk High School.

Several mismatches, related for instance to the entry points to the support services and the way support provision is announced on institutional websites, have been identified. The role of technologies in the provision of support - from entry point to educational exit points - is also diffuse. This means that while sectors like higher education and the Swedish Folk High School come under the umbrella or jurisdiction of level-1 policies as a fundamental dimension of democratic provision of education for all, analysis of level-2 policies gives rise to a problematic picture in relationship to praxis. This draws attention to the need for making information accessible in multiple modalities and multiple named languages, as well as the need for user-friendly online interfaces for accessing information about studies in higher education and adult education.

In general, all universities and university colleges have dedicated pages where the provision of support for peripheral named groups is accounted for. What is surprising is that there are no university (or Swedish Folk High School) institutions that explicitly highlight provision of support for their staff. At an overarching level, there are two main target groups for which universities and university colleges provide support: students with a permanent disability and students in need of language support in their academic writing and their academic studies generally. Disabilities that emerge on account of accidents or other life crises are not included in the support services offered explicitly through websites. In fact, the requirement to provide formal documentation highlighting the permanent nature of disabilities as one of the first steps is an important indicator of the practiced policy related to support. 
The support provision by the Swedish Folk High School institutions takes a different pathway altogether. The analysis indicates that this sector is not under obligation to provide support. Their support provision is in fact direct, since as part of their agendas, they tend to target student populations in the margins in terms of their functionality, interests, background, language and other needs. Three main groups are addressed in the support provision by this sector: people with functional disabilities, people who have not completed their studies at the upper-secondary level and adult immigrants. The support is also primarily presented in written Swedish. Locating information about support provision in the Swedish Folk High School sector therefore requires more than a simple website search. This is interesting in light of the fact that (some) Swedish Folk High School institutions target students with disabilities and new adult migrants in a more clear-cut manner; at an overall level, they target a more diverse population of students compared to the university sector.

Available support presented on the websites is marked by what new students can expect - for instance, who to contact for further information - and the nature of support the institution makes available - for instance, technologies that students can access in various ways. These can be differentiated in terms of diverse, overlapping assistive and disruptive (i.e. replacing what existed previously) technologies and, following our earlier work (see, for instance, Bagga-Gupta et al. 2016; Holmström and Bagga-Gupta 2017), in terms of human technologies (wherein a human assistant supports a student directly as a mentor or note-taker, for example); digital technologies (including software and hardware that are made accessible for either direct download or in specific physical on-campus rooms); analogue technologies (like specific literature, including Braille translations), physical and spatial technologies (technologically infused on-campus rooms); mobility technologies (like GPS and wheelchairs); and temporal technologies (that frame extensions made available to students for their studies and/or specific tasks like examinations). All these technologies, both human and nonhuman, are neither neutral, nor good or bad as such; they illuminate the situated-distributed nature of support provision and the ways in which support is framed. The present study illustrates how higher education and the Swedish Folk High School account for their support, which in some cases is directly linked to specific named groups. Such linkages contribute to creating the identity of the peripheral named group, as in for instance the use of technologies that target specific disabilities. An illustration of this is Stava Rex for dyslexia, or 
the use of the microphone by the teacher in a room equipped with a loopset. The latter is a result of a national higher education policy for inclusiveness. Thus, supportive technologies, as a crucial part of the support offered, both contribute to creating inclusive environments and, in their being earmarked for those who have special needs, also mark the people who use them as in need of such 'special' support (särskilt stöd). Thus, accessibility is framed in terms of three specific groups in the case of the Swedish Folk High School: those who have special needs, those who have not completed their upper secondary school and those who have migrated to Sweden as adults. Swedish Folk High School institutions streamline their resource applications to governmental bodies, as well as their programmes and activities, to fit these groups. For instance, they have access to resources through the National Agency for Special Education (SPSM) ${ }^{5}$ for grants based upon the categorisation of functional disabilities of their student groups.

While our findings indicate that there are substantial differences in terms of expectations and aims placed on participants in the two sectors examined in this study, the sectors also share similarities. Heterogenous participants in the Swedish Folk High School often aim to access a university or university college eventually. Across time, university policies illustrate that the sector has an awareness of issues of access for an increasingly diverse student population, in terms of language, functionality, ethnicity, and other factors. However, catering to a widening participation for all (see UHR 2019) in higher and adult education is based upon the demographic profiles only of students as compared to the make-up of society at large. Apart from gender, staff heterogeneity within the Swedish Folk High School and university sectors remains invisible in our dataset.

An important implication of the take-home message of this study is the need to re-centre the existing narrative regarding the named groups focused on here from alternative perspectives. Bagga-Gupta (2018) highlights how the act of naming, besides constituting a hegemonic stance from a mainstream 'norm', is also the result of the power, or possibility, to perpetrate such hegemonic stances in the very practice of naming (i.e. 'We' name the 'Other', because 'We' can); that is, 'naming someone or something as someone or something' has consequences (2018: 129, original emphasis; see also BaggaGupta 2019). For instance, a number of pages and documents in Swedish universities address issues of widening participation in line with political agendas at the local, national and global levels (the latter in relation to the United Nations Agenda 2030 sustainable development goals), thus creating 
rather immobile framings that aim to capture extremely complex and mobile praxis that resist neat ready-to-use instructional manuals and models. It is in this sense that praxis as a critical act may reveal universities' ambitions to function as national institutions that create and sanction specific support pathways for the 'common good' to change history. However, this type of change often means that students who can avail themselves of such support need to be named as in need of it, and are then expected to adjust to its framings, rather than the other way round. Institutional policies become practice and practice becomes policy, at times resulting in absurd situations. A recent case can illustrate such absurdities, pointing to the dialectic of policy and practice framings: a deaf student was prevented from completing an English-language course as part of their teacher education programme because the special pedagogical arrangements at the institution did not include alternative examination forms to evaluate the student's knowledge of the phonetic system of English. ${ }^{6}$

The findings of this study highlight how in their display of practices of support, university institutions, to a greater extent than Swedish Folk High School ones, contribute towards a homogenisation of such praxis; here, policy texts and regulations are seamlessly entangled with what is offered by the institutions, why, and with what aims. Our practiced policy perspective illuminates the nature of such entanglements, most importantly in terms of who and what is made (in)visible in the process. Policy and practices of inclusion and integration in the Swedish Folk High School have on the other hand been more difficult to identify using the logic of practiced policy, since the demand of support is what motivates the offer and not the other way around; in the university sector, conversely, the offer of support is available for the students who can 'adjust' to it by demonstrating their eligibility to avail themselves of specific support. The present study indicates that praxis, in the Swedish Folk High School, means addressing participants' needs for inclusion and integration beyond the level of formal understandings of policy and regulations. The classical praxis-oriented deliberation of what 'ought to be done', in our case in terms of what can potentially change the possibilities to integrate and include students in an educational community, is tackled in substantially different ways in university and Swedish Folk High School institutions. We argue that this constitutes a central issue that has its roots in - and has implications for - the ways in which people in society imagine and value higher education and adult education as praxis. 
Sangeeta Bagga-Gupta is Professor of Education at Jönköping University, Sweden. Her research interests include communication, identity and learning from ethnographically framed, multiscalar, sociocultural, decolonial theoretical framings. She is the director of Lärandepraktiker i och utanför skolan (LPS, www.ju.se/lps) and the scientific leader of Communication, Culture and Diversity (CCD, www.ju.se/ccd). She currently leads the Swedish Research Council project PAL, 'Participation for all?’ (www.ju.se/ccd/pal). Email: sangeeta.bagga-gupta@ju.se

Giulia Messina Dahlberg is Senior Lecturer in Education at the Department of Education and Special Education, University of Gothenburg, Sweden. Her research deals with the communicative practices of individuals performing a range of tasks both inside and outside institutional educational settings that are located across the boundaries of physical and virtual sites. She is particularly interested in the ways in which such boundaries are created and negotiated in action to provide (or prevent) access to learning and participation. In her research and course development, she has recently engaged with the conditions for equity and inclusion provided for students with disabilities in higher education. She is an active researcher in the Swedish Research Council project PAL, 'Participation for all?'

Email: giulia.messina.dahlberg@gu.se

Sylvi Vigmo is a Senior Lecturer in Education at the Department of Education, Communication and Learning, University of Gothenburg, and currently a guest lecturer at Jönköping University. Her research interest is grounded in the changing teaching and learning landscape in which people's learning as belonging to and participating in virtual sites continues to challenge the educational framing of higher education. Of particular research interest are conditions for digitalisation in higher education and how these impact teaching and learning practices. Email: sylvi.vigmo@gu.se 


\section{Notes}

1. Swedish: 'Tillängligt och öppet för alla. Många folkhögskolor erbjuder anpassad undervisning, socialt stöd och en tillgänglig miljö för deltagare med funktionsnedsättning. Det finns också kurser som vänder sig särskilt till dig med funktionsnedsättning’.

2. University of Gothenburg https://www.gu.se/studera/plugga-pa-universitetet/ studera-med-funktionsnedsattning.

3. This Swedish Folk High School changed its name and logo in the autumn of 2019 to SIMA.

4. Mo Gård https://www.mogard.se/

5. SPSM is a national authority that is governed by the Ministry of Education (Utbildningsdepartementet). https://www.spsm.se/om-oss/other-languages/english/.

6. This student's case was taken up by a national non-profit organisation that supports deaf individuals across sectors and the student won the case in the spring of 2020 with the support of legal counsel.

\section{References}

Anderson, B. (1991), Imagined Communities (New York: Verso).

Bacchi, C. (2009), Analysing Policy: What's The Problem Represented to Be? (Melbourne: Pearson Australia).

Bagga-Gupta, S. (2018), 'Going beyond "single grand stories” in the Language and Educational Sciences: A turn towards alternatives', Aligarh Journal of Linguistics 8 (Special issue: Language Across Disciplines): 127-147. http://urn.kb.se/resolve?urn = urn:nbn:se: hj:diva-42343 (accessed 7 September 2020).

Bagga-Gupta, S. (2019), 'Learning Languaging matters: Contributions to a turn-on-turn reflexivity', in S. Bagga-Gupta, A. Golden, L. Holm, H. P. Laursen, and A. PitkänenHuhta (eds), Reconceptualizing Connections between Language, Literacy and Learning (Rotterdam: Springer), 103-125.

Bagga-Gupta, S. (forthcoming, 2021), 'Analytical engagement with "promises in policy": Illuminating equity and language policy AS participation in and across the wilderness of contemporary human life', in F. Bonacina-Pugh (ed.), Language Policy as Practice (London: Palgrave McMillan).

Bagga-Gupta, S. and G. Messina Dahlberg (forthcoming), 'Disentangling participation across scales: Perspectives on practices of access, communication and inclusion in contemporary lives', Outlines: Critical Practice Studies (Special Issue: Transmethodology: Research Beyond Proceduralism).

Bagga-Gupta, S., G. Messina Dahlberg and Y. Winther (2016), 'Disabling and enabling technologies for learning in higher education-for-all. Issues and challenges for whom?', Informatics. Special issue: Information and Communication Technology in Higher Education 3, no. 4: 21-39. https://doi.org/10.3390/informatics3040021. 
Bakhtin, M. (1981), The Dialogic Imagination: Four Essays, trans. C. Emerson and M. Holquist (Austin, TX: University of Texas).

Bernhard, D. and P. Andersson (2017), 'Swedish Folk High Schools and inclusive education’, Nordic Studies in Education 37, no. 2: 87-102. https://doi.org/10.18261/ issn.1891-5949-2017-02-03.

Bonacina-Pugh, F. (2012), 'Researching "practiced language policies": Insights from conversation analysis', Language Policy 11: 213-234. https://doi.org/10.1007/ s10993-012-9243-X.

Butler, J. (1997), Excitable Speech: A Politics of the Performative (London: Routledge).

Discrimination Act (2008:567). (Stockholm: Government Offices of Swedent). https:// www.government.se/information-material/2015/09/discrimination-act-2008567/.

Fejes, A., M. Dahlstedt, M. Olson, and F. Sandberg (2018), Adult Education and the Formation of Citizens (New York: Routledge).

Folkhögskolarnas informationstjänst (2017), Tio snabba om folkhögskolan [Ten quick about Folk High School]. https://www.folkhogskola.nu/globalassets/dokument-och-filer/ tio-snabba-om-folkhogskolan.pdf (accessed 7 September 2020).

Gramsci, A. (1975), Il materialismo storico [Historical Materialism] (Torino: Editori Riuniti).

Heath, S. (1983), Ways with Words: Language, Life, and Work in Communities and Classrooms (Cambridge: Cambridge University Press).

Holmström, I. and S. Bagga-Gupta (2017), “"Va sa han?” - Technologies and participation strategies in mainstream school settings', in S. Bagga-Gupta (ed.) Marginalization Processes across Different Settings. Going beyond the Mainstream. (Newcastle-uponTyne: Cambridge Scholars Publishing), 164-186.

Kemmis, S. (2012), 'Researching educational praxis: spectator and participant perspectives', British Educational Research Journal 38, no. 6: 885-905.

Kyndt, E., V. Donche, K. Trigwell, and S. Lindblom-Ylänne (2017), Higher Education Transitions: Theory and Research (London: Routledge).

Lave, J. and E. Wenger (1991), Situated Learning: Legitimate Peripheral Participation (Cambridge: Cambridge University Press).

Marres, N. and E. Weltevrede (2013), 'Scraping the social?', Journal of Cultural Economy 6, no. 3: 313-335. https://doi.org/10.1080/17530350.2013.772070.

Promemoria U2017/03082/UH (2017), Brett deltagande i högskoleutbildning [Widening participation in HE]. Regeringskansliet website. https://www.regeringen.se/4a0cf3/ globalassets/regeringen/dokument/utbildningsdepartementet/hogre-utbildning/ brett-deltagande-i-hogskoleutbildning.pdf (accessed 7 September 2020).

Prop. 2001/02:15 (2001), Den öppna högskolan [The Open University]. Riksdagen website. https://data.riksdagen.se/fil/4BBA1C19-6222-4029-80D8-D22E3851A23A (accessed 7 September 2020). 
SFS (2015), Svensk författningssamling. Förordning om statsbidrag till folkbildningen. [Law concerning state funding for folk education] (2015:218). Riksdagen website. https:// www.riksdagen.se/sv/dokument-lagar/dokument/svensk-forfattningssamling/ forordning-2015218-om-statsbidrag-till_sfs-2015-218 (accessed 7 September 2020).

Sweden.se (2020), 'Higher Education and Research'. https://sweden.se/society/higher -education-and-research/ (accessed 7 September 2020).

UHR (2018), En inblick $i$ studiesituationen för studenter med funktionsnedsättning [A look at the study situation of students with functional disabilities] (2018:5). https:// www.uhr.se/globalassets/_uhr.se/publikationer/2018/eurostudent_vi_final.pdf (accessed 7 September 2020).

UHR (2019), En högskola för alla [One university for all]. https://www.uhr.se/om-uhr/ nyheter/2019/goda-exempel-ska-bidra-till-battre-situation-for-studenter-med -funktionsnedsattning/ (accessed 7 September 2020).

UKÄ (2018), Universitet och högskolor. Årsrapport 2018 [Universities and colleges: Annual report 2018]. https://www.uka.se/download/18.661e864c1639ebc31e7750/ 1556787265197/rapport-2018-05-30-arsrapport-2018.pdf (accessed 7 September 2020).

Utrikesdepartementet (2008), Konvention om rättigheter för personer med funktionsnedsättning [Convention on the rights for persons with disability] (2008:26). https:// www.un.org/disabilities/documents/convention/crpd_swedish_corrected.pdf (accessed 7 September 2020). 